\title{
EVIDENCE FOR THE CHEMICAL MODIFICATION OF COLLAGEN IN RHEUMATOID ARTHRITIS
}

\author{
BY \\ F. S. STEVEN* \\ Department of Physiology and Biochemistry, St. Salvator's College, University of St. Andrews
}

In the past the insoluble collagen of connective tissue has been examined largely as its corresponding derived gelatin. Gelatins prepared from normal and rheumatoid collagens were demonstrated to be slightly different in their primary structures (Steven, 1964a). The so-called "insoluble collagen" has now been solubilized by the $\alpha$-amylase technique first described by Nishihara (1963) for steer-hide collagen and later adapted for aged human tendon by Steven (1964b). Native collagen from rheumatoid knee joint synovial tissue and hip joint acetabular tissue have been isolated by the Nishihara technique and compared with the collagen extracted from knee joint and synovial tissue and Achilles and patellar tendons taken post mortem from subjects with no known history of rheumatoid arthritis. The collagens extracted from aged human tissues are highly crosslinked (Steven, 1965) and do not yield more than 4 to 10 per cent. dry weight soluble gelatin after heating to $100^{\circ} \mathrm{C}$. for one hour at $p \mathrm{H} \mathrm{7}$, unlike the monomer, tropocollagen, which is quantitatively converted to a gelatin under these conditions.

Electron microscope examination of the Nishihara extracted normal collagen dissolved in $0.1 \mathrm{M}$ acetic acid demonstrated the highly polymerized nature of this collagen (Fig. 1, overleaf), which on higher magnification showed the typical collagen periodicity (Fig. 2, overleaf) observed in native collagen of intact tissue.

The primary structures of collagens extracted from normal and rheumatoid tissues are being compared after enzyme digestion followed by fingerprinting analysis in this laboratory. Native tropocollagen is made up from a tightly wound triple helix composed of alternating polar and non-polar regions. Short peptide appendages are attached to the helix and these have been referred to as telopeptides by Rubin, Pfahl, Speakman, Davison, and Schmitt (1963). The triple helical part of tropocollagen is digested only by a special class of enzymes defined as collagenases by Mandl (1961). Other proteolytic enzymes are capable of a strictly limited type of

\footnotetext{
* Present Address: University of Manchester, Rheumatism Research
} Centre and Department of Medical Biochemistry. digestion which is confined to the telopeptide regions of native tropocollagen (Hodge, Highberger, Deffner, and Schmitt, 1960; Rubin and others, 1963; Steven, 1963). The Nishihara extracted collagen is also attacked by pepsin in the region of the telopeptides (Steven, 1965) with consequent depolymerization to subunits similar to those produced by the action of pepsin on tropocollagen.

\section{Present Investigations}

In the present study a simple technique has been developed which demonstrates a chemical modification of collagen obtained from joints severely affected by rheumatoid arthritis as compared with collagen from normal synovial tissue and tendons. Pronase is a proteolytic enzyme with a wide specificity; however, it can only digest native tropocollagen in the telopeptide regions (Tyson, 1964). The thermal stability of Nishihara solubilized normal collagens is unaffected after pronase treatment, whereas collagens extracted from rheumatoid tissue have greatly reduced thermal stability. Any change in the thermal stability of these polymerized collagens after incubation with a small quantity of pronase for half an hour must be caused by enzyme attack at a non-helical part of the collagen protofibril followed by a local destabilizing effect at the site of digestion which in turn is reflected in an increase in the soluble nitrogen fraction obtained after thermal denaturation under standard conditions.

\section{Experimental Conditions}

The collagens solubilized by the Nishihara technique from six normal knee joint synovia, six tendons, and eight rheumatoid tissues were brought to $p \mathrm{H} 7 \cdot 0-7 \cdot 5$ by suspending the protein in approximately $4 \mathrm{M}$ sodium acetate, and the excess salts were then removed by washing the insoluble protein in water. The collagens were then suspended in $0.01 \mathrm{M} \mathrm{CaCl}{ }_{2}$ containing pronase obtained from the Kaken Chemical Company, Tokyo. The enzyme substrate ratio was within the range 1:2 and 1:4 $\times$ $10^{3}$. This ratio may be determined only after thermal denaturation and total nitrogen analysis, 


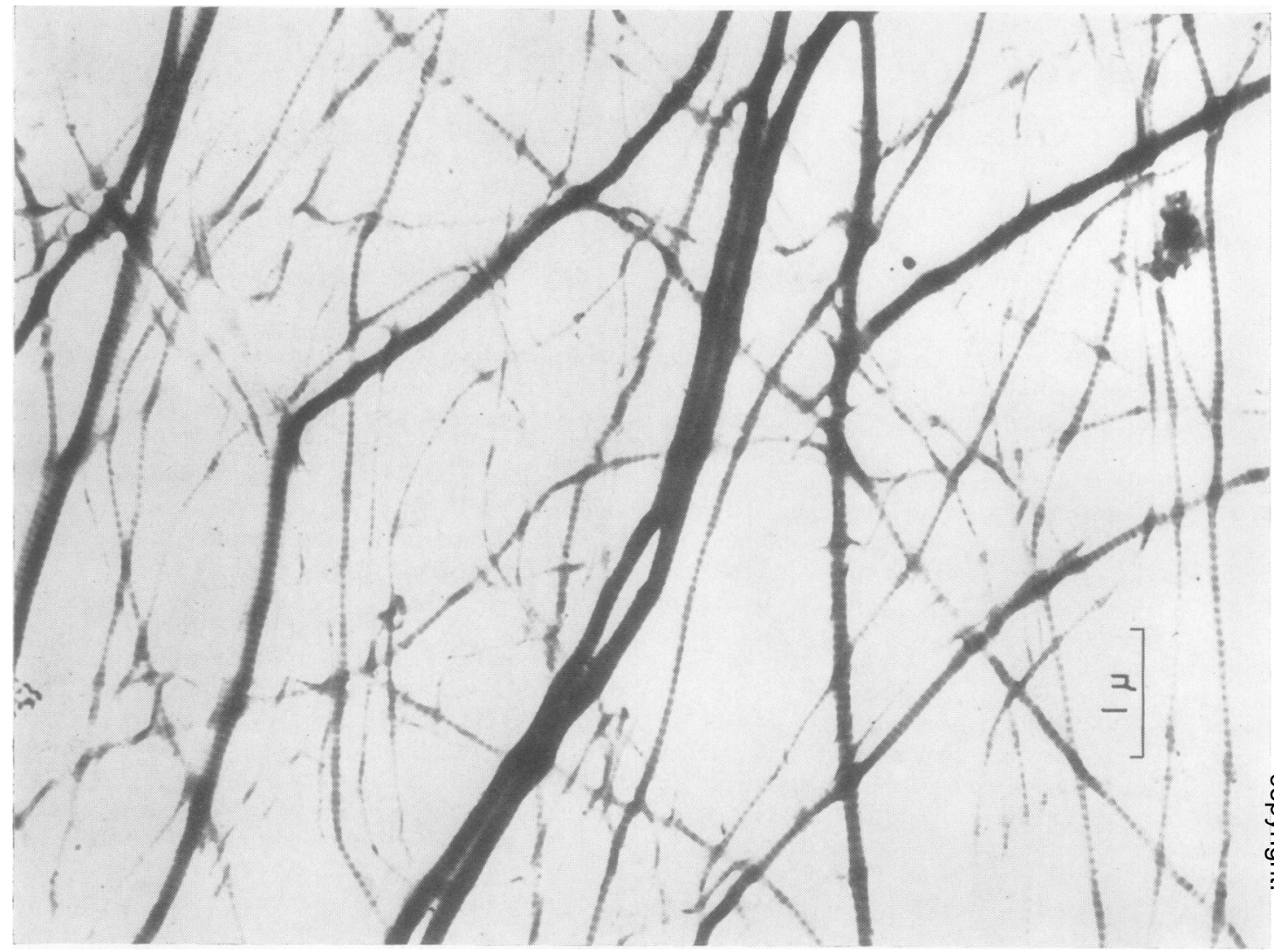

Fig. 1.-Nishihara solubilized normal collagen in $0.1 \mathrm{M}$ acetic acid stained with 2 per cent. uranyl acetate (by courtesy of Dr. J. K. Candlish).

and as a result the ratio can be only approximately judged from experience at the time of digestion. In these experiments this ratio is not necessarily identical in each case but is within the limits stated above; the actual ratios are given for the graphs in Fig. 3 where necessary. The reaction mixture was shaken at $18^{\circ} \mathrm{C}$. and samples of insoluble collagen were removed at 10-minute intervals. The fibrous protein was then dropped into a boiling tube containing $20 \mathrm{ml}$. boiling water and was kept in a boiling water bath for one hour. This operation immediately inactivated the enzyme and also denatured the collagen. The nitrogen in the soluble fraction (gelatin) and the residual insoluble fraction was determined by microkjeldahl analysis. In each case the quantity of gelatin formed in the absence of pronase was determined as a control and this was found to be about 4 per cent., with one exception in which 10 per cent. was obtained.

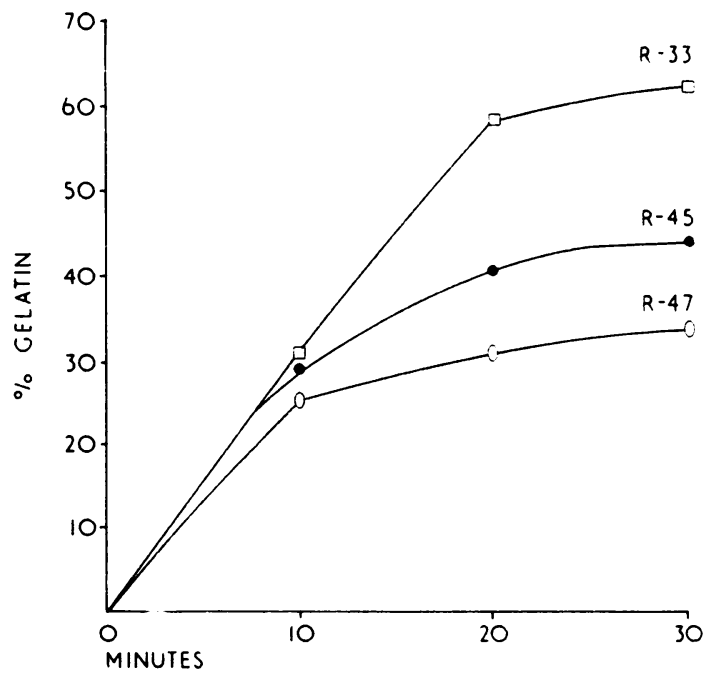

Fig. 3.-Pronase digestion of rheumatoid collagens. The enzyme action is measured by the increase in gelatin formation after denaturation when the collagen was incubated with the enzyme at $18^{\circ} \mathrm{C}$., $p \mathrm{H}$ 7.0-7.5, for $30 \mathrm{~min}$. Enzyme substrate ratios were 1:2,000, 1:1,400, and $1: 1,400$ for $R-33, R-45$, and $R-47$ respectively. 


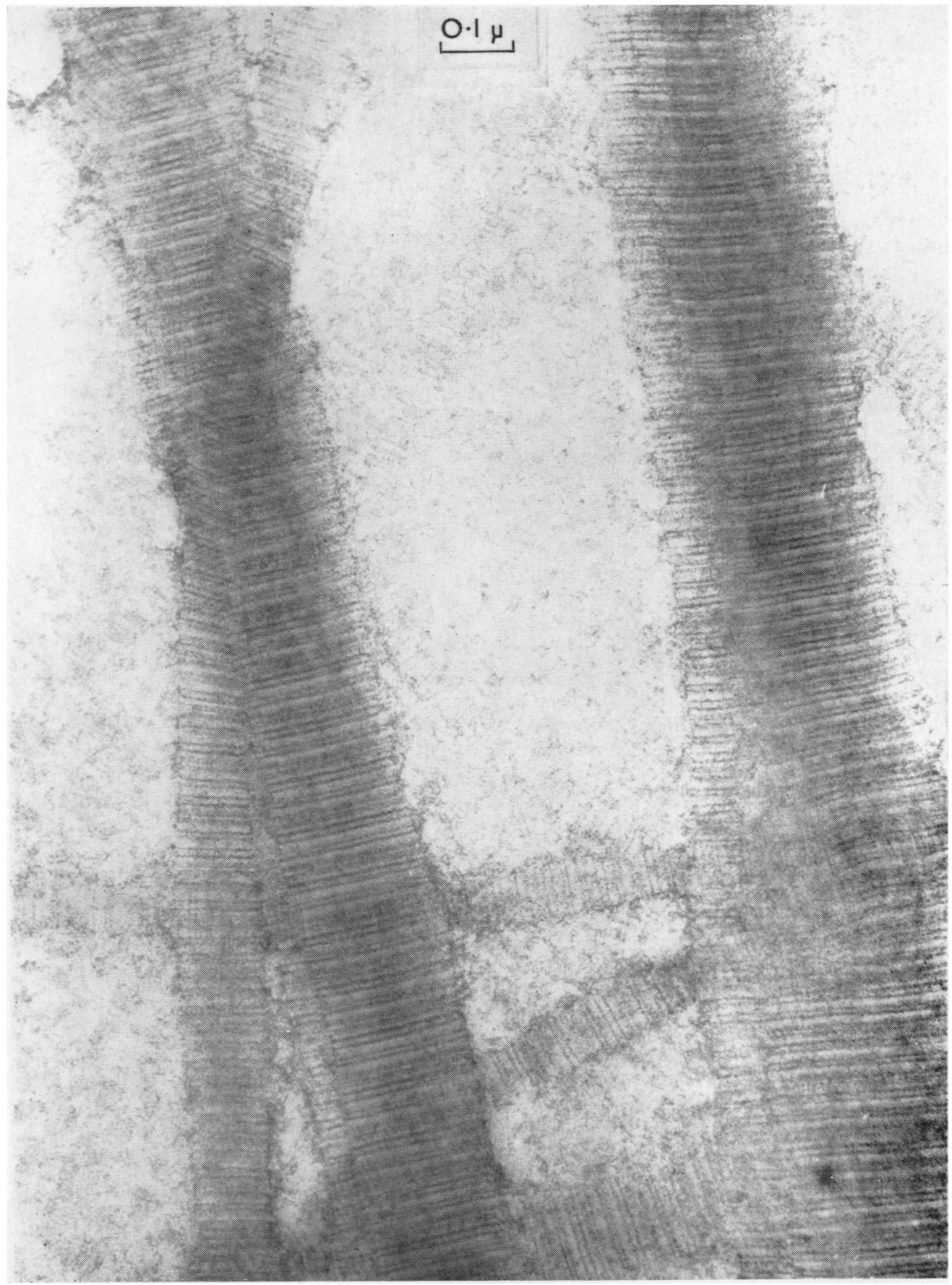

Fig. 2.-Higher magnification of Fig. 1, in which the typical periodicity of native collagen can be seen (by courtesy of Dr. J K. Candlish). 


\section{Results}

Collagens from normal tissues showed no increase in gelatin formation in the presence of pronase even after 24 hours. This would indicate that the enzyme was not digesting the telopeptide regions of normal collagen at this very low enzyme substrate ratio, since some destabilization would be expected to have taken place (Steven, 1965). Collagens from rheumatoid tissues were attacked by pronase and showed a marked increase in gelatin formation after enzyme treatment; three typical examples are presented in Fig. 3. The degree of gelatin formation varied with the individual collagen preparations and this might be accounted for if it were assumed that the rheumatoid connective tissues contained normal collagen as well as a variable amount of abnormal collagen. It is suggested that the abnormal collagen might have points of local disorder along the length of the polymerized collagen fibrils and that the pronase attacks these disordered sites. The partially digested collagen is then destabilized to such an extent that it is capable of depolymerization on thermal denaturation with the subsequent formation of a soluble gelatin. It may be argued that the age of the collagen, which influences the degree of crosslinking and thermal stability, might possibly cause the observed differences in normal and rheumatoid collagen. It may well be that in rheumatoid tissue the turnover rate of collagen differs from that in normal tissue and that even in an old patient the rheumatoid collagen might conceivably be relatively young collagen in the biological sense. These arguments cannot explain the observed facts, since any variation in the degree of cross-linking is taken into account in the controls in which no enzyme was added and all the rheumatoid collagens show an increase in gelatin formation with time of pronase digestion in contrast to the normal collagens which show no change at all.

The results clearly show that the primary structure of collagen derived from rheumatoid tissue is different from that of normal collagen. This difference may be either a cause or a result of the disease or may even be the result of general inflammation of the diseased tissue. At the moment it is important to realize that the collagen is chemically modified in rheumatoid tissues. It is hoped to examine the peptide bonds cleaved by pronase in rheumatoid collagens.

I wish to express my thanks to Dr. J. K. Candlish for permission to publish the two electron microscope pictures and for his generous help in this study, to Prof. Callan for permission to use the microscope, to Mr. J.
Mackie for technical assistance with the microscope, and to $\mathrm{Mr}$. A. Grieve for technical assistance in the preparation of the Nishihara solublized collagens.

I am indebted to the Arthritis and Rheumatism Council and to Dr. G. R. Tristram for the provision of a research fellowship.

\section{REFERENCES}

Hodge, A. J., Highberger, J. H., Deffner, G. G. J., and Schmitt, F. O. (1960). Proc. nat. Acad. Sci., 46, 197.

Mandl, I. (1961). Adv. Enzymol., 23, 163.

Nishihara, T. (1963). Jap. Pat. $9295 / 62$ Collagen Currents $(4,-386)$.

Rubin, A. L., Pfahl, D., Speakman, P. T., Davison, P. F. , and Schmitt, F. O. (1963). Science, 139, 37.

Steven, F. S. (1963). Biochem. biophys. Acta, 77, 466. (1964a). Ann. rheum. Dis., 23, 300.

(1964b). Ibid., 23, 405.

(1965). Biochem. biophys. Acta, in Press.

Tyson, I. R. (1964). Unpublished work.

Démonstration de la modification chimique du collagène dans l'arthrite rhumatismale

\section{RÉSUMÉ}

On a développé un procédé pour démontrer unêr modification chimique du collagène des articulations arthritiques rhumatismales en comparaison avec le collagène des tissus synoviaux et des tendons normaux. La thermostabilité des collagènes normaux solubilisés par la méthode de Nishihara n'est pas affectée par la pronase tandis que celle des collagènes extraits des tissus rhumatoïdes est fortement réduite. On conclut que la structure primaire du collagène rhumatoïde est différente de celle du collagène normal. Cette différence peut être la casue ou le résultat de la maladie, ou bien une manifestation de l'inflammation générale du tissu malade.

Demostración de la modificación química del colágeno en la artritis reumatoide

\section{SUMARIO}

Se señala un procedimiento para demostrar una modificación química del colágeno de articulaciones artríticas reumatoides en comparación con el colágeno de los tejidos sinoviales y de tendones normales. La termostabilidad de colágenos normales solubilizados por el método de Nishihara no se ve afectada por la pronasa mientras que la de los colágenos extraidos de tejidos reumatoides se ve fuertemente reducida. Se concluye que la estructura primaria del colágeno reumatoide es diferente de la del colágeno normal. Esta diferencia puede ser la causa o el resultado de la enfermedad o, quizas, una manifestación de la inflamación general del tejido enfermo. 